\title{
O entre lugar do ser real e sua representação, nas bordas de um exercício auto ficcionalizante
}

Ana Beatriz Ferreira Batista

- Olhos! Dê-me olhos!

Hoffmann

Chegava até a afirmar: é loucura acreditarmos que a criação - nas artes e nas ciências - seja ato livre da vontade, pois o entusiasmo necessário para criar não parte de nós, sendo desencadeado pela ação de algum princípio superior, externo a nós.

Hoffmann

O objeto fatal que portava não era faca. Nem mesmo em seu corpo másculo possuía uma, tão flácido seu membro ia murchando, murchando. Mas ela pensou: espetarei meu broche nesta lapela como a marca sagrada de um gesto infame. Chegávamos ao pico máximo daquela correria.

Não podemos deixar desabar, aliás construções concretas não podem ser desfeitas em cachoeiras. Você realmente deseja meu corpo? Abro as pernas na representação The Centre of the World, de Jules Adolphe Chauvet. Século XIX, toma. A mata é profunda, mesmo sem rei, meu povo ainda sobe de joelhos a escadaria da Penha.

Escolho um chapéu novo. Porque estes cornos, estes chifres, pesam mais que o demônio da palavra democracia. Estou nua, fatigada e comida - mas para sua fome sirvo tão bem quanto um farto banquete preparado por deuses. Não posso ser canonizada. Isto me tornaria ilegal, portando falsa identidade em forma de calças de linho - tecido muito fino nesta estação tropical que nos guarda.

Porque fui eu quem carregou aquele broche em uma viagem de avião. É meu e nomeado: camafeu. O que você fez com sua vergonha? Exibi-a em pelos. Já estava bem usada, no entanto, a qualidade dos sabonetes garantiam que estivesse sempre 
perfumada. Você quer colocar um pouco mais? Essa extensão é infinita.

O muito por ele tentado - meu corpo exposto e fatiado como vianda provocava efeito reverso: ele não conseguia me ver, nem me pegar. O nome da cona, era tudo o que eles queriam ouvir. Evita, alguns gritavam. Onde está sua vergonha? Caixinha redonda, oval ou oblonga. Antigamente usavam-na para guardar rapé. Jura? Atualmente se usa como epíteto para cona. Agora o segredo: ele nunca foi duro.

Tudo aquilo podia ser resumido a uma representação pictórica do século XVI intitulada The Anabaptist's Bath, de Heinrich Aldegrever. O corpo esburacado escorrendo. Mas não ouse transformar este corpo, esta cidade, no esgoto dos seus pesadelos. Rosa contava delicadamente as contas do Rosário. Falta muito? Por que a representação do meu corpo torna-se etérea ao ponto de extinguir qualquer reflexo?

Naquele buraco cabia de tudo. Pênis, bananas, bebês, bolinhas... Mas estas balas que adoçam sua língua agora, são embaladas no papel reciclável do meu ódio. Câmera e livro. Poderíamos simplificar a dualidade não dicotômica dos objetos nomeando-os pesos. Sim. Pesos sustentados pelo corpo. Um teorema bem concreto. Qual o calibre da sua pistola? Vinte e dois, ele disse. Sinto muito querido, isso não existe.

A rapariga até pensou que ganharia um dinheirinho com aquilo, cúmulo de ilusão. São apenas gomas de mascar, estilo Juquinha, ou sete belo - se preferir sabor morango. Apliquei tantas incisões naquela face ao ponto de não reconhecer-me mais ao espelho. Aquilo era eu? Decalcada? Poderia chamar por meu próprio nome a imagem extraída de mim? E o que seria um eu? Pronome? Possessão? Desejo de um profundo encontro com o nódulo que conferisse sentido a toda uma existência? Meu eu, meu eu. Que lugar seguro.

Mas via tantas de mim produzidas nas séries tridimensionais do espetáculo cotidiano vivido nas ruas, que até me desconhecia. Simplesmente vivo ao respirar por todos os poros. É belo tudo o que há de horrível no meu eu pasteurizado. Mas por favor, não quero ser abandonada por meus amigos. Não poderia permitir que o eu me abandonasse tão completamente sem que pudesse convocar-me tu ou nós em pleno entendimento amorfo.

Aquelas incisões, operações, lâminas e facas, esculpiram-me graciosa - disto 
sabia. O sal das lágrimas vertidas pelos olhos, já não garantiam pronome algum. E agora meu ventre poderá expandir-se? Dilatar-se para a vida? Pai, eu não quero mais brigar com a mamãe. Mas será que ela perdoará eu ter sido tão levada? Meu corpo líquido, meu corpo sólido, meu corpo vivo, “... quero dizer, acomodar-se ao real, encontrar sua satisfação e seu destino no mundo sensível e perecível.”. 